\title{
Post-Infectional Biochemical Changes in Cymbopogon martinii (Roxb.) Wats and Cymbopogon citratus (DC) Stapf. Due to Leaf Rust Disease
}

\author{
Phatik Tamuli ${ }^{1}$, Mamoni Saikia ${ }^{2}$, Paran Boruah ${ }^{3}$ \\ ${ }^{1}$ Department of Botany, Darrang College, Tezpur, India; ${ }^{2}$ Department of Botany, D. K. D. College, Dergaon, India; ${ }^{3}$ Division of Me- \\ dicinal Aromatic and Economic Plants, North East Institute of Science and Technology, Jorhat, India. \\ Email: tamulip@yahoo.com
}

Received March $14^{\text {th }}, 2013$; revised April 15 ${ }^{\text {th }}, 2013$; accepted May $12^{\text {th }}, 2013$

Copyright (C) 2013 Phatik Tamuli et al. This is an open access article distributed under the Creative Commons Attribution License, which permits unrestricted use, distribution, and reproduction in any medium, provided the original work is properly cited.

\begin{abstract}
Post-infectional changes in sugars, ascorbic acid, protein, phenols, chlorophyll and carotene of two Cymbopogons viz., Cymbopogon martinii and Cymbopogon citratus due to leaf rust caused by Puccinia nakanishikii (Diet) were investigated. All the biochemical constituents decreased in plants infected by the fungal pathogen.
\end{abstract}

Keywords: Ascorbic Acid; Biochemical Changes; Carotene; Chlorophyll; Cymbopogon Martini; Cymbopogon Citrates; Phenols; Protein; Sugars

\section{Introduction}

Cymbopogon martinii (Roxb) Wats (Palmarosa) and Cymbopogon citratus (DC) Stapf. (Lemongrass) are essential oil bearing aromatic plants belonging to the genus Cymbopogon. The oil Cymbopogon martini is used as the base for fine perfumery and is valued because of its geraniol contents. Besides the perfumery value, the oil has a great wound healing effect. Cymbopogon citratus is one of the sources of citral, an important monoterpene aldehyde, large quantity of which are being utilized for production of ionones, vitamin A and geraniol besides the use in perfumery soaps and cosmetics.

Although C. citratus and C. martinii are two economically important essential oil yielding grasses, due to the infection by rust fungus, these two species of Cymbopogons show serious losses in terms of herb yield, oil content and its quality. Rust fungi are obligate parasites and are highly destructive. Boruah and Bordoli [1] reported the pathogen associated with rust disease of Cymbopogons as Puccinia nakanishikii (Diet).

The ultimate impact of host-pathogen interaction is manifested in alteration of composition of nutritional and structural metabolites in the host [2]. Metabolic changes due to fungal infection have been reported in various plants [3-6]. The present investigation was undertaken to study the changes in sugars, ascorbic acid, protein, phenols, chlorophyll, carotene, respiration and transpiration during pathogenesis in Cymbopogon martinii and Cymbopogon citratus.

\section{Materials and Methods}

\subsection{Sugar}

Following the Indole reaction method [7] both reducing and non-reducing sugars were estimated taking glucose as standard.

$2 \mathrm{~g}$ of fresh leaf samples from respective cases were boiled in $20 \mathrm{ml}$ of distilled water for 20 minutes. The extract was purified by treating with $5 \% \mathrm{ZnSO}_{4}$ and $5 \%$ $\mathrm{Ba}(\mathrm{OH})_{2}$ solution and then filtered and volume was adjusted to $250 \mathrm{ml}$ and further diluted to give readings at $480 \mathrm{~nm}$ with $1 \%$ Indole reagent. The estimation of sugars was carried out in a Unicum SP 600 series 2 Spectrophotometer. Non-reducing sugar was calculated by subtracting the value of reducing sugar from total sugar. Results were expressed as $\mathrm{g}$ of sugar per $100 \mathrm{~g}$ of fresh leaf.

\subsection{Ascorbic Acid}

Fresh leaves $(5 \mathrm{~g})$ were extracted with $5 \%$ metaphosphoric acid solution and made up to $50 \mathrm{ml}$. Ascorbic acid content was estimated volumetrically using 2,6-dichlorophenol indophenol as indicator [8]. 


\subsection{Protein}

Protein content of plant samples was estimated by the method of Lawry et al. [9] and Wildman and Jagendorf [10] using bovine albumin as standard.

\subsection{Phenols}

Phenolic compounds were extracted by boiling $5 \mathrm{~g}$ plant material with $80 \%$ alcohol for 5 min [11]. Total phenols in the alcohol extract were estimated by employing Folin-Ciocalteau reagent [12] and Catechol was used as standard.

\subsection{Chlorophyll and Carotene}

Chlorophyll \& carotene contents were estimated by the following method [13]. $100 \mathrm{mg}$ of fresh leaves from each variety were collected and extracted separately in $15 \mathrm{ml}$ of acetone in a test tube by standing tubes overnight in dark. The extract was centrifuged at $5000 \mathrm{rpm}$ for 15 minutes. The supernatant was taken and absorbance measurements were recorded at 662, 664 and $440.5 \mathrm{~nm}$ in a Unicum SP 600 Series 2 Spectrophotometer. The chlorophyll and carotene contents were calculated by incorporating the absorbance values into the following equation.

$$
\begin{aligned}
& \mathrm{Chl}_{\mathrm{a}}=9.78 \mathrm{~A}_{662}-0.99 \mathrm{~A}_{664} \\
& \mathrm{Chl}_{\mathrm{b}}=21.40 \mathrm{~A}_{664}-4.65 \mathrm{~A}_{662} \\
& \mathrm{Car}=4.69 \mathrm{~A}_{440.5}-\mathrm{Chl}_{\mathrm{a}}+\mathrm{Chl}_{\mathrm{b}} 0.26
\end{aligned}
$$

\section{Results and Discussion}

\subsection{Sugar Content}

The reducing and non-reducing sugar contents decreased in infected plants of the species from healthy ones (Table 1). Percent losses of reducing sugars were 45.312 and 45.454 in C. martinii and C. citratus respectively. Similarly, non-reducing sugars were recorded as $22.845 \%$ and $28.264 \%$ in C. martinii and C. citratus respectively.

A similar trend of decreased sugar levels in diseased plants was observed by Prasad et al. [5] and Nema [6]. The depletion of sugars during host-parasite interaction might be due to increased respiration or utilization of sugars by the fungi which depends on the capability of fungi to secrete carbohydrate degrading enzyme [5]. Nema [6] suggested that reduction in sugars during disease development might be due to utilization of sugars probably for energy and synthetic reactions involved in multiplication of the pathogen.

\subsection{Ascorbic Acid Content}

In infected plants ascorbic acid content was decreased than healthy ones in both the cases (Table 1). In C. mar- tinii percent loss was recorded as 28.260 while in the case of C. citratus it was 27.272.

The decreased level of ascorbic acid in infected plants might be due to ascorbic acid degenerating enzymes either by the fungus alone or by the activity of the hostpathogen complex. Reddy et al. [3] observed a gradual loss in ascorbic acid content in infected fruits of acid lime (Citrus aurantifolia).

\subsection{Protein Content}

It was observed that higher amount of protein content was available during healthy stage which gradually decreased in diseased plants of both the species (Table 1). Result indicated that $32.197 \%$ of protein was lost due to infection in C. martinii while it was $32.207 \%$ in the case of $C$. citratus.

Decreasing in protein content might be due to degradation of the host proteins by the proteolytic enzymes secreted by the pathogens. Similar results were also reported by Prasad et al. [5] in muskmelon fruits infected with fruit-rot fungi.

\subsection{Phenol Content}

A decreasing manner in phenol content was observed in rust-infected plants in both the Cymbopogons (Table 1). Percent loss in phenol content was recorded as 25.093 and 29.859 in C. martinii and C. citratus respectively.

Khatri et al. [4] have observed that the amount of phenols reduced in rice leaves due to infection by Entyloma oryzae. Working on betelvine leaves infected with Colletotrichum glocosporioides, Naik et al. [14] had reported a rapid decline in phenolic compounds. Nema [6] was of the opinion that the growth of the pathogen is inhibited by the phenolic compounds but when the pathogen is successful in causing disease the ratio of phenolic compound changes, and in highly susceptible cultivar, the phenolic compounds mostly deplete.

\subsection{Chlorophyll and Carotene}

In the present investigation, it was noticed that chlorophyll-a, Chlorophyll-b and Carotene metabolism gradually declined in the diseased condition of the Cymbopogon (Table 1).

Chlorophylls played a major and positive role in the synthesis of carbohydrates. The scenario was very much different in a diseased plant which leads to degradation of chlorophyll. Carbohydrate synthesis in leaves had a positive correlation with chlorophyll content. The initial stage of disease development led to the breakdown ofchlorophyll which probably facilitated subsequent estab lishment of the parasite. This content was supported by 
Table 1. Changes of host metabolites in relation to disease.

\begin{tabular}{ccccccc}
\hline \multirow{2}{*}{$\begin{array}{c}\text { Metabolic } \\
\text { constituents }\end{array}$} & \multicolumn{3}{c}{ C. martinii } & \multicolumn{3}{c}{ C. citratus } \\
\cline { 2 - 7 } & Healthy (\%) & Diseased (\%) & Percent loss/gain & Healthy (\%) & Diseased (\%) & Percent loss/gain \\
\hline Reducing sugar & 1.792 & 0.980 & 45.312 & 1.639 & 0.894 & 45.454 \\
Non-reducing sugar & 15.942 & 12.300 & 22.845 & 14.053 & 10.081 & 28.264 \\
Total sugar & 17.734 & 13.050 & 26.412 & 15.692 & 10.895 & 30.369 \\
Chlorophyll-a & 6.042 & 4.620 & 23.535 & 5.292 & 3.084 & 41.723 \\
Chlorophyll-b & 5.352 & 3.829 & 28.456 & 4.930 & 3.092 & 37.281 \\
Carotene & 0.734 & 0.629 & 14.305 & 0.496 & 0.331 & 33.266 \\
Protein & 4.842 & 3.283 & 32.197 & 5.210 & 3.532 & 32.207 \\
Ascorbic acid & 0.184 & 0.132 & 28.260 & 0.132 & 0.96 & 27.272 \\
Phenol & 130.032 & 97.428 & 25.093 & 135.020 & 94.704 & 29.859 \\
\hline
\end{tabular}

the findings of Allen [15]. During infection, the chloro phyll molecules were destroyed and further synthesis of chlorophyll was checked which in turn disturbed the synthesis of sugar.

Along with the decrease of $\mathrm{Chl}_{\mathrm{a}}$ and $\mathrm{Chl}_{\mathrm{b}}$, the carotene synthesis was also decreased. After attaining a particular level, the chlorophyll content didn't increase because it was protected from photooxidation by the caroteneids of leaf [16]. This decrease in the carotene content in palmarosa and lemongrass might be due to environmental factors [17].

\section{REFERENCES}

[1] P. Boruah and D. N. Bordoloi, "Leaf Rust of C. martinii Var Motia in North-East India," Indian Phytopathology, Vol. 37, No. 3, 1984, p. 584.

[2] P. Tamuli, P. Boruah and R. Samanta, "Biochemical Changes in Essential Oil Bearing Aquilaria malaccensis Lamk. under Pathogenesis," Journal of Spices and Aromatic Crops, Vol. 13, No. 2, 2004, pp. 87-91.

[3] B. C. Reddy, P. V. Reddy and P. Gopala Raju, "Post Infection Changes in Acid Lime Fruits Caused Aspergillus niger," Indian Phytopathology, Vol. 37, No. 1, 1984, pp. 185-187.

[4] R. K. Khatri, R. P. Shastry, P. N. Reddy and K. G. Nema, "Metabolic Changes in Rice Leaves Infected by Entyloma oryzae," Indian Phytopathology, Vol. 38, No. 4, 1985, pp. 769-771.

[5] B. Prasad, O. P. Verma and L. N. Daftari, "Biochemical Changes in Safflower Leaves Caused by Rust Infection," Indian Phytopathology, Vol. 29, No. 1, 1976, pp. 53-58.

[6] A. G. Nema, "Sugar and Phenol Contents of Betelvine Leaves after Inoculation with Leaf Spot Bacterium," Indian Phytopathology, Vol. 42, No. 1, 1989, pp. 31-37.

[7] G. Ashwell, "Colorimetric Analysis of Sugar," In: S. P. Colowick and N. O. Kaplan, Eds., Methods in Enzymology, Vol. 3, 1957, pp. 73-105.
[8] O. A. Bessey and C.G. King, "The Distribution of Vitamin $\mathrm{C}$ in Plant and Animal Tissues and Its Determination," The Journal of Biological Chemistry, Vol. 103, 1933, pp. 687-698.

[9] O. A. Lawry M. J. Rosenbrough, F. A. Lewis and R. J. Randall, "Protein Measurement with Folin Phenol Reagent," The Journal of Biological Chemistry, Vol. 193, No. 1, 1951, pp. 263-275.

[10] S. Wildman and A. Jagendorf, "Leaf Proteins," Annual Review of Plant Physiology, Vol. 3, 1952, pp. 131-147.

[11] D. Chandramohan, A. Mahadevan and G. Rangaswami, "Studies on Some Biochemical Properties of Leaf Tissues of Amaranthus tricolor as Related to Resistance to Infection by Alternaria sp," Indian Phytopathology, Vol. 20, 1967, pp. 109-113.

[12] H. G. Bray and W. V. Thorpe, "Analysis of Phenolic Compounds of Interest in Metabolism," Methods of Biochemical Analysis, Vol. 1, 1955, pp. 27-52.

[13] J. A. Bailey, "Phytoalexin Production by Leaves or Pisum sativum in Relation to Senescence," Annals of Applied Biology, Vol. 64, No. 2, 1969, pp. 315-324. doi:10.1111/j.1744-7348.1969.tb02881.x

[14] M. K. Naik, P. C. Hiremath and S. V. Hiremath, "Post Infectional Changes in the Betelvine Leaves Infected with Colletotrichum gloeosporioides," Indian Phytopathology, Vol. 41, No. 3, 1988, pp. 370-372.

[15] P. J. Allen, "Changes in the Metabolism of Wheat Leaves Induced by Infection with Powdery Mildew," American Journal of Botany, Vol. 29, No. 6, 1942, pp. 425-435. doi: $10.2307 / 2437306$

[16] M. Lawandowska and P. G. Jarvis, "Changes in Chlorophyll and Carotenoid Content, Specific Leaf Area and Dry Shading and Season," New Phytologist, Vol. 79, No. 2, 1977, pp. 247-256. doi:10.1111/j.1469-8137.1977.tb02202.x

[17] G. J. Horvath and A. F. Danial, "Effect of Light Intensity on the Formation of Carotenoids in Normal and Mutant Maize Leaves," Phytochemistry, Vol. 11, No. 1, 1972, pp. 183-187. doi:10.1016/S0031-9422(00)89987-2 